УДК 342.9

DOI https://doi.org/10.32849/2663-5313/2020.1.19

Наталія Коваленко,

докт. юрид. наук, доиент,

професор кафедри полічейського права

Національної академії внутрішніх справ

\title{
ПОНЯТТЯ ТА ОЗНАКИ АДМІНІСТРАТИВНО-ПРАВОВОГО РЕЖИМУ
}

Метою статті є вивчення наукових поглядів на поняття «адміністративно-правовий режим», а також встановлення його сутності та головних ознак. Розглянуто наукові підходи до визначення поняття «адміністративно-правовий режим», визначено його об'єкт та предмет. На основі проведеного аналізу сформульовано авторське визначення досліджуваного поняття. Встановлено сутність адміністративного режиму, його специфіку та головні ознаки. Визначено, що адміністративно-правовий режим - особлива форма правового регулювання суспільних відносин, яка базується на поєднанні комплексу юридичних, організачійних і технічних процедур та адміністративно-правових засобів і визначає міру можливої й належної поведінки суб'єктів, надає особливої спрямованості суспільним відносинам у сфері публічної влади. Наголошено на доцільності визнати адміністративно-правові режими комплексним засобом правового регулювання, зумовленим иільовим призначенням певних відносин в адміністративній сфері, що потребують спеціальної процесуальної регламентацій, особливого правового статусу суб'єктів правовідносин, специфічного механізму реалізації їх правосуб'єктності й окремого комплексу заходів захисту їхніх прав. Зроблено висновок, що для кожного зазначеного адміністративно-правового режиму визначальними є характеристики особливого методу регулювання (імперативного), особливого зв'язку між учасниками правовідносин (владні відносини), обмеженість сфери застосування (відносини, шо охоплюються предметом адміністративного права), мета застосування. У вузькому формальному аспекті сутність адміністративного режиму як певного поєднання адміністративно-правових засобів розкривається в низиі елементів, до яких варто зарахувати правову регламентацію діяльності в режимних сферах; систему дозволів; пряму заборону окремих видів суспільних відносин; коло прав та обов'язків учасників правовідносин; забезпечення необхідного обліку й контролю деяких видів діяльності; застосування різних видів юридичної відповідальності за порушення чинних правил.

Ключові слова: правовий режим, адміністративно-правовий режим, визначення, специфіка, головні ознаки.

Постановка проблеми. Одним із різновидів правових режимів є адміністративноправові режими. Зрозуміло, що галузеві режими зумовлені специфікою предмета, форм і методів правового регулювання відповідної галузі права, тому для виявлення особливостей адміністративно-правових режимів необхідно визначити специфіку адміністративно-правових відносин і юридичних засобів впливу на них. Водночас у спеціальній літературі немає єдиного підходу до інтерпретації цих феноменів, як немає й конвенціональної дефініції поняття «адміністративно-правовий режим».

Зазначимо, що сьогодні, у період динамічних перетворень у соціально-економічній, політичній (насамперед у системі організації державної влади) та інших сферах, адміністративне регулювання соціальних процесів набуває в Україні особливо актуального значення. Оскільки останніми десятиріччями відбулися істотні зміни в усіх суспільних системах Укра- їни, зумовлені проведеними соціально-економічними, політичними перетвореннями, адміністративною реформою, реформою державної служби тощо, відповідні трансформації торкнулися й предмета адміністративно-правового регулювання. Серед останніх науковці як найголовніші виділяють такі:

- по-перше, докорінні зміни стосовно сторін адміністративно-правових відносин;

- по-друге, перехід від командно-розпорядницького «чистого адміністрування» до власне адміністративно-нормативного регулювання;

- по-третє, розширення арсеналу регулятивних методів за рахунок дозволів, рекомендацій, стимулів, насамперед економічних;

- по-четверте, перенесення акцентів 3 єдиноцентричного державного регулювання на галузеву координацію діяльності суб'єктами державного управління;

- по-п'яте, модернізацію державного регулювання економічної сфери; 
- по-шосте, посилення контрольно-наглядової функції держави;

- по-сьоме, введення й розвиток таких форм державного впливу, як реєстрація, ліцензування, сертифікація суб'єктів господарської або соціально-культурної діяльності, адміністративний договір;

- нарешті, посилення ролі держави в аспекті захисту прав та інтересів учасників відносин у сфері діяльності органів виконавчої влади [1, с. 20-21].

Метою статті є вивчення наукових поглядів на поняття «адміністративно-правовий режим», а також встановлення його сутності та головних ознак.

Аналіз останніх досліджень і публікацій. Питання, пов'язані 3 концепцією «адміністративно-правовий режим», розглядали такі вчені, як, наприклад, А. В. Басов, Д. Н. Бахрах, К. В. Бережна, В. М. Завгородня, С. В. Ківалов, О. О. Крестьянінова, Т. П. Мінка, І. С. Нельговський, І. С. Розанов та ін.

Виклад основного матеріалу. За загальним правилом, відносини, що становлять предмет адміністративного права, - це широкий комплекс суспільних відносин, які виникають у зв'язку з реалізацією функцій державної виконавчої влади, змістом якої є управління суспільством [2, с. 8]. Отже, можемо погодитись із поглядом Д. Н. Бахраха, згідно з яким адміністративно-правовий режим супроводжує діяльність органів і посадових осіб виконавчої влади під час ï взаємодії з громадянами й організаціями, а також між собою у процесі реалізації ними своїх посадових обов'язків, регулювання різноманітних об'єктів і процесів [3, с. 482]. Інакше кажучи, об'єкт адміністративно-правового режиму становлять управлінські відносини, тобто такі, в яких суб'єкти права найчастіше перебувають у супідрядності один щодо одного.

Крім специфіки предметного змісту, для розуміння адміністративно-правового режиму важливо осягнути спрямованість методів адміністративно-правового регулювання, тобто прийомів і способів, що використовуються під час регламентації адміністративно-правових відносин для досягнення визначених цілей.

Тут доцільно згадати теоретичне дослідження О. О. Крестьянінова, в якому він порівнює правові режими в методичному аспекті й доходить висновку, що режими загальнодозвільного профілю характерні для сфери цивільного й сімейного права; режими дозвільного профілю - для сфери охорони навколишнього природного серед- овища; режими, засновані на позитивних зобов'язаннях, переважають у сфері адміністративного, фінансового (податкового) й виправно-трудового права [4, с. 568].

До того ж потрібно мати на увазі, що саме адміністративно-правові режими через свій тісний зв'язок з владно-управлінськими відносинами пов'язані з можливими ситуаціями екстраординарного обмеження прав і свобод людини, які закріплені Конституцією України [5], тому зазначеним режимам найбільш притаманний імперативний метод правового регулювання.

Здійснивши загальнотеоретичний огляд категорії адміністративно-правового режиму, звернемося до конкретних її дефініцій, запропонованих науковцями [6].

Так, Д. Н. Бахрах доводить, що адміністративно-правовий режим як певне об'єднання адміністративно-правових способів регулювання виявляється в централізованому порядку, імперативному методі правового впливу та асиметрії суб'єктів правовідносин [7, с. 483], тобто вважає головними рисами цього режиму визначальну роль вищих органів влади, імперативність методу та відносини влади-підпорядкування.

Дещо іншої думки дотримується I. C. Розанов, який зазначає, що адміністративно-правовий режим - це сукупність установлених у законодавчому порядку правил діяльності, дій або поведінки громадян і юридичних осіб, а також порядок реалізації ними своїх прав у певних умовах (ситуаціях), забезпечення та підтримання суверенітету й оборони держави спеціально створеними для цієї мети службами державного управління [8, с. 87], віддаючи визначальні позиції законодавчому оформленню, змістовому наповненню («сукупність правил») і спеціальному суб'єктові.

Зі свого боку, С. В. Ківалов переносить акценти на мету існування адміністративноправового режиму, характеризуючи його як самостійний правовий інститут з організаційними забезпечувальними елементами, спрямований на встановлення оптимальних із погляду держави відносин у конкретній порівняно вузькій, однак життєво важливій сфері, яка забезпечує безпеку особи, суспільства й держави [9, с. 194-195].

Т. П. Мінка насамперед звертає увагу на формальний аспект адміністративно-правового режиму, визначаючи його як правову форму, що відображає специфіку впливу комплексу правових способів на суспільні відносини, які охоплюються предметом адміністративного права [10, с. 126].

А. В. Басов, розглядаючи конкретний адміністративно-правовий режим - режим 
надзвичайного стану, трактує його як «систему погоджених правових норм, які визначають підстави для введення режиму, мету введення, порядок його введення, суб'єкта, який уповноважений вводити просторові та часові межі дії, особливий режим діяльності органів державної влади й управління, що дає змогу обмежувати права і свободи громадян і права юридичних осіб, накладення на них додаткових обов'язків» $[11$, с. 9], тобто робить наголос на системно-структурній побудові зазначеного явища й характеристиках існування.

На думку В. М. Завгородньої, адміністративно-правовий режим може бути визначений як сукупність юридичних конструкцій, що встановлюється й реалізується в окремій сфері відносин, які становлять предмет адміністративного права, та забезпечує публічні інтереси за допомогою адміністративно-правових засобів [12, с. 35]. Дослідниця вводить до кола визначальних рис характеристику «забезпечення публічних інтересів», що, на нашу думку, відповідає сучасному спрямуванню адміністративного права.

К. В. Бережна, вивчаючи конкретний різновид адміністративно-правового режиму - митно-правовий режим транзиту, визначає його як сукупність правових норм, що залежно від заявленої мети переміщення товарів та інших предметів визначають порядок такого переміщення; умови перебування товарів та інших предметів на митній теритоpiї чи поза митною територією держави; встановлюють коло прав та обов'язків учасників правовідносин, які при цьому виникають; обсяг і зміст митних процедур, що здійснюють митні органи $[13$, с. 6$]$. Тобто дослідниця репрезентує як головні організаційно-процедурні аспекти режиму, зумовлені метою його існування.

Беручи до уваги, що всі цитовані визначення виходять із розуміння адміністративно-правового режиму як особливого порядку правового регулювання, створеного поєднанням конкретних юридичних засобів, водночас можна помітити, що науковці по-різному оцінюють аспекти організаційноправового і юридично-технічного забезпечення його реалізації, мету його існування, суб'єктно-компетенційні характеристики.

Аналіз визначень, наданих фахівцями, дає змогу стверджувати, що для кожного адміністративно-правового режиму визначальними $\epsilon$ характеристики особливого методу регулювання (імперативного), особливого зв'язку між учасниками правовідносин (владні відносини), обмеженість сфери застосування (відносини, що охоплюються предметом адміністративного права), мета застосування. У вузькому формальному аспекті сутність адміністративного режиму як певного поєднання адміністративно-правових засобів розкривається в низці елементів, до яких варто зарахувати:

- правову регламентацію діяльності в режимних сферах;

- систему дозволів;

- пряму заборону окремих видів суспільних відносин;

- коло прав та обов'язків учасників правовідносин;

- забезпечення необхідного обліку й контролю деяких видів діяльності;

- застосування різних видів юридичної відповідальності за порушення чинних правил.

3 огляду на вищезазначене доцільно визнати адміністративно-правові режими комплексним засобом правового регулювання, зумовленим цільовим призначенням певних відносин в адміністративній сфері, що потребують спеціальної процесуальної регламентації, особливого правового статусу суб'єктів правовідносин, специфічного механізму реалізації їх правосуб'єктності й окремого комплексу заходів захисту їхніх прав.

Отже, підсумовуючи, зосередимось на головних ознаках адміністративно-правового режиму:

- сфера їх застосування - вони встановлюються у сфері управлінської діяльності органів влади;

- мета їх застосування - забезпечення публічних інтересів, насамперед мінімізація актуальних та уникнення потенціальних загроз;

- особливе методичне забезпечення адміністративно-правовим режимам притаманне позитивне методичне орієнтування, тобто покладення на суб'єктів (державні органи, посадові особи, організації, підприємства, громадян) обов'язків діяти певним чином для досягнення конкретних цілей; при цьому орієнтування може мати характер загальнонормативної орієнтації, конкретного припису, доручення здійснити те чи інше юридично значуще діяння;

- специфічна сукупність видів юридичної відповідальності - порушення правил режиму супроводжується вжиттям заходів адміністративного примусу й подальшим притягненням до юридичної відповідальності.

Отже, з огляду на наведене вище, можна зробити висновок, що адміністративно-правовий режим - особлива форма правового регулювання суспільних відносин, яка базується на поєднанні комплексу юридичних, організаційних і технічних процедур та адміністративно-правових засобів і визначає міру можливої й належної поведінки суб'єктів, 
надає особливої спрямованості суспільним відносинам у сфері публічної влади.

Тут маємо згадати вдалий вислів I. Є. Нельговського, який сказав, що теорія адміністративно-правових режимів «заповнить істотну нішу в юридичній науці, оскільки саме в іï межах доцільні уважне вивчення та систематизація <..> багатьох питань, що виникають в інших специфічних сферах управлінських відносин» [14, с. 8-12]. Дійсно, найширший обсяг функціонування, подвійна природа замкнених у зазначений обсяг відносин - управлінських і тих, які потребують управління, соціальна важливість мети застосування роблять адміністративно-правові режими однією з визначальних категорій сучасного права.

Нині з упевненістю можна сказати, що термін «адміністративно-правовий режим» міцно закріпився у вітчизняній правовій доктрині. I якщо раніше це поняття розроблялося переважно в межах загальної теорії права, то нині поняття «адміністративноправовий режим» зміцнило й дедалі поширює свої позиції як в адміністративно-правовій науці, так і в юридичній практиці.

\section{Висновки}

Аналіз визначень адміністративно-правового режиму, наданих фахівцями, дає змогу стверджувати, що для кожного зазначеного режиму визначальними $€$ характеристики особливого методу регулювання (імперативного), особливого зв'язку між учасниками правовідносин (владні відносини), обмеженість сфери застосування (відносини, що охоплюються предметом адміністративного права), мета застосування. У вузькому формальному аспекті сутність адміністративного режиму як певного поєднання адміністративно-правових засобів розкривається в низці елементів, до яких варто зарахувати правову регламентацію діяльності в режимних сферах; систему дозволів; пряму заборону окремих видів суспільних відносин; коло прав та обов'язків учасників правовідносин; забезпечення необхідного обліку й контролю деяких видів діяльності; застосування різних видів юридичної відповідальності за порушення чинних правил.

\section{Список використаних джерел:}

1. Научная библиотека диссертаций и авторефератов. URL: http://www.dissercat.com/ content/administrativno-pravovye-rezhimyv-teorii-administrativnogo-prava-i-praktikegosudarstvennog\#ixzz4uvqkYZKI (дата звернення: 23.10.2019)

2. Адміністративне право України : підручник / за заг. ред. Т. О. Коломоєць. К., 2009. 480 с.

3. Бахрах Д. Н., Россинський Б. В., Старилов Ю. Н. Административное право: учебник для вузов. 3-е изд., пересмотр. и доп. Москва : Норма, 2008. $816 \mathrm{c}$.

4. Крестьянінов О. О. Адміністративноправові режими як особливий інститут державного управління. Держава і право. 2001. Вип. 12. $568 \mathrm{c}$.

5. Конституція України : прийнята на 5-й сесії Верховної Ради України 28 червня 1996 р. / уклад. В. Кузнєцов. Харків : Фактор, 2008. 131 с.

6. Волкова Н. В. Про митний пост «Акцизний» та імпорт фармацевтичної продукції. Вісник Академії митної служби України. Серія «Право». 2009. № 2 (3). С. 66-72.

7. Бахрах Д. Н., Россинський Б. В., Старилов Ю. Н. Административное право : учебник для вузов. 3-е изд., пересмотр. и доп. Москва : Норма, 2008. $816 \mathrm{c}$

8. Розвиток ринку земель сільськогосподарського призначення в Україні: аналітична доповідь / Нац. інститут стратегічних досліджень. Київ : НІСД, 2014. 29 с.

9. Адміністративне право України / за ред. С. В. Ківалова. Одеса, 2003. 632 с.

10. Мінка Т. П. Особливості класифікації адміністративно-правових режимів. Форум права. 2012. № 3. C. 453-458.

11. Басов А. В. Адміністративно-правовий режим надзвичайного стану : дис. ... канд. юрид. наук : 12.00.07. Харків, 2007. 228 с.

12. Завгородня В. М. Категорія «адміністративно-правовий режим» у понятійному апараті адміністративного права. Правовий вісник Украйнської академії банківської справи. 2012. № 1 (6). С. 31-35.

13. Бережна К. В. Митно-правовий режим транзиту в Україні : автореф. дис. ... канд. юрид. наук : 12.00. Київ, 2003. 21 с.

14. Андрейцев В. І. Суверенній Україні - нову «Земельну Конституцію» (концептуальні підходи до підготовки проекту Кодексу Законів України про землю). Право Украйни. 1999. № 8. С. 58-65.

The purpose of the article is to study the scientific viewes on the concept of "administrative-legal regime", as well as to determine its essence and main features. Scientific approaches to the definition of the term "administrative-legal regime" are considered, its object and subject are defined. On the basis of the analysis the author's definition of the concept under study is formulated. The essence of the administrative regime, its specifics and main features are established. It is determined that the administrative-legal regime is a special form of legal regulation of public relations, which is based on the combination of a complex of legal, organizational and technical procedures and administrative-legal means and determines the degree of possible and proper behavior of the subjects, gives a special focus to public relations in the sphere of public power. It is emphasized that it is expedient to recognize administrative and legal regimes as a complex means of legal 
regulation, predetermined by the purpose of certain relations in the administrative sphere, requiring special procedural regulation, a special legal status of the subjects of legal relations, a specific mechanism for the realization of their legal personality and a separate set of measures for their protection. It is concluded that for each of these administrative and legal regimes, the characteristics of a particular method of regulation (imperative), a special connection between the parties to a legal relationship (power relations), a limited scope of application (relations covered by the subject of administrative law), a purpose are decisive. In the narrow formal aspect, the essence of the administrative regime as a certain combination of administrative and legal means is revealed in a number of elements, which should include legal regulation of activity in the regime spheres; permit system; direct prohibition of certain types of social relations; the range of rights and obligations of participants in legal relationships; ensuring the necessary accounting and control of certain activities; the application of various types of legal liability for violation of existing rules.

Key words: legal regime, administrative and legal regime, definitions, specifics, main features. 